\title{
Korelasi Antar Sikap Disiplin Terhadap Budaya Sekolah Di SD Negeri Kompleks BTN Pemda Kota Makassar
}

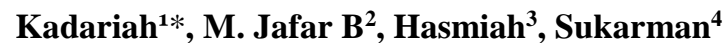 \\ ${ }^{1234}$ Manajemen Pendidikan Universitas Terbuka, Makassar \\ ${ }^{1}$ Email: kadariah@ecampus.ut.ac.id, ${ }^{2}$ Email: jafarb@ecampus.ut.ac.id \\ ${ }^{3}$ Email: hasmiah@ecampus.ut.ac.id ${ }^{4}$ Email: sukarman@ecampus.ut.ac.id \\ *Corresponding author
}

\begin{abstract}
This study aims to explain the correlation between disciplinary attitudes towards school culture in the SD Negeri BTN Makassar City Government. Data were analyzed by correlational methods and quantitative approaches. This type of research is an Ex-Post Facto study by examining the correlation between discipline attitudes and school culture in the SDN BTN Makassar City Government. The results of the analysis of the research data processing revealed that there was a positive and significant effect between the attitude of discipline on school culture in students of the SDN BTN Makassar City Government. This means that the disciplined attitude of students as evidenced by compliance, loyalty and good order will create a school culture by enforcing norms or rules and habits / habits that are getting better so that it will create a comfortable and conducive school atmosphere for learning and achievement for students in elementary school Negeri BTN Makassar City Government. This is evidenced by the many achievements achieved by students both between schools in Makassar City and between schools in South Sulawesi.
\end{abstract}

Keywords: Discipline; School Culture.

\begin{abstract}
Abstrak. Penelitian ini bertujuan untuk menjelaskan korelasi antar sikap disiplin terhadap budaya sekolah Di SD Negeri BTN Pemda Kota Makassar. Data dianalisis dengan metode korelasional dan pendekatan kuantitatif. Jenis penelitian ini adalah penelitian ExPost Facto dengan mengkaji korelasi antara sikap disiplin dan budaya sekolah di SD Negeri BTN Pemda Kota Makassar. Hasil analisis dari pengolahan data penelitian diketahui bahwa ada pengaruh positif dan signifikan antara sikap disiplin terhadap budaya sekolah pada siswa SD Negeri BTN Pemda Kota Makassar. Hal ini berarti sikap disiplin siswa yang dibuktikan dengan kepatuhan, kesetian dan ketertiban yang baik akan menciptakan budaya sekolah dengan menjalankan penegakan norma atau aturan dan kebiasaaan/habit yang semakin baik sehingga akan tercipta suasana sekolah yang nyaman dan kondusif untuk belajar dan berprestasi bagi siswa di SD Negeri BTN Pemda Kota Makassar. Hal tersebut dibuktikan dengan banyaknya prestasi yang di raih oleh para siswa baik antara sekolah se Kota Makassar maupun antar sekolah di Sulawesi Selatan
\end{abstract}

Kata Kunci: Sikap disiplin; Budaya Sekolah

\section{PENDAHULUAN}

Sekolah merupakan lembaga pendidikan formal, tempat peserta didik belajar, berinteraksi, di didik dan dibimbing. Di sekolah, peserta didik tidak sekadar menimbah ilmu, tetapi dididik, dibimbing, dan didewasakan. Lembaga pendidikan formal diharapkan membawa peserta didik untuk memahami budayanya khususnya budaya positif dan menjadikan budaya tersebut sebagai kebiasaan berperilaku dalam rutinitas seharihari yang berorientasi pada terwujudnya bangsa yang berbudaya dan beradab (Rahmatullah, Inanna, \& Nurdiana, 2019). Peserta didik diberi ilmu yang akan bermanfaat baginya kelak dalam bersosialisasi dalam masyarakat. Peserta didik dibekali dengan nilai-nilai, aturan, sopan santun, tata krama, adat dan budaya. Tujuannya 
adalah agar peserta didik dapat disiplin dan patuh dengan peraturan yang telah dibuat. Keberadaan peraturan-peraturan yang dibuat disekolah, diharapkan peserta didik dapat bertindak dengan tanggung jawab seperti yang diharapkan.

Pendidikan merupakan aspek yang sangat penting dalam menunjang kemajuan bangsa di masa depan. Sumber daya manusia yang berkualitas dapat terwujud apabila pendidikan diselenggarakan secara konprehensip dan memiliki karakter (Rahmatullah \& Inanna, 2017). Memegang teguh karakter bangsa Indonesia akan menjadikan kita bangsa yang maju, berdaulat, adil, makmur dan bermartabat (Inanna, 2018).

Melalui pendidikan manusia sebagai subjek pembangunan dapat dididik, dibina dan dikembangkan potensi potensinya. Pendidikan berfungsi untuk menyiapkan peserta didik untuk terjun ke kehidupan yang nyata. Persiapan ini berkaitan dengan kedudukan peserta didik sebagai calon warga negara yang baik, warga bangsa dan calon pembentuk keluarga baru, serta mengemban tugas dan pekerjaan dikemudian hari. Sebagai calon penerus bangsa, peserta didik yang dibina dan diharapkan mampu untuk mempunyai karakter disiplin dalam menjalankan tugasnya disegala aspek. Selain itu, pendidikan perlu berperan dalam mengawal generasi bangsa agar memiliki pola pikir, pola sikap, dan pola tindak yang sesuai dengan jati diri bangsa (Rahmatullah, 2018).

Pembentukan karakter disiplin dapat ditanamkan sejak anak berada di sekolah. Aspek terpenting dalam aplikasi karakter disiplin di sekolah adalah warga sekolah, mencakup kepala sekolah, staf, guru, dan siswa, sehingga dalam suatu sekolah atau lembaga pendidikan mempunyai tata tertib yang diharapkan mampu ditaatin oleh seluruh warga sekolah. Sikap disiplin itulah yang harus ditumbuhkan dilingkungan sekolah sehari-hari. Sikap disiplin sangat penting dimiliki oleh manusia agar kemudian muncul nilai-nilai karakter yang baik lainnya. Pentingnya penguatan nilai karakter disiplin didasarkan pada alasan bahwa sekarang banyak terjadi perilaku menyimpang yang bertentangan dengan norma kedisiplinan. Perilaku tidak disiplin yang lain contohnya adalah membuang sampah sembarangan tempat dan datang terlambat.

Disiplin adalah tindakan yang menunjukan perilaku tertib dan patuh pada berbagai ketentuan dan peraturan. Disiplin diri merujuk pada latihan yang membuat orang merelakan dirinya untuk melaksanakan tugas tertentu atau menjalankan pola perilaku tertentu, walaupun bawahannya adalah malas. Seorang murid dikatakan berdisiplin apabila ia mengikuti peraturan yang ada di sekolah. Begitu pula dengan karakter bertanggung jawab di sekolahan. Bukan hanya disiplin yang sekarang jadi perhatian, namun tanggung jawab peserta didik sudah mulai memudar. Sebagai seorang siswa dengan berbagai ketentuan dan aturan yang dibuat disekolahan apakah siswa tersebut dapat bertanggung jawab atas apa yang ada. Misalnya tanggung jawab siswa setiap hari senin yaitu mengikuti upacara bendera dengan atribut lengkap. Dengan adanya budaya dan iklim sekolah tersebut apakah siswa dapat dengan konsisten memegang tanggung jawab yang diberikan sekolahan untuknya. Contoh lain misalnya adalah mengikuti perlombaan, seorang siswa yang bertanggung jawab harusnya dengan sepenuh hati memenangkan perlombaan atas nama sekolahannya.

Keberhasilan dan kualitas pendidikan di pengaruhi oleh dua factor, yaitu: faktor internal dan faktor eksternal. Faktor internal antara lain mencakup sarana fisik, kualitas guru dan prestasi siswa, sedangkan faktor ekternal antara lain adalah sikap dan budaya sekolah. Jika sikap dan budaya sekolah baik maka akan mempengaruhi kualitas pendidikan yang ada. Budaya sekolah yang baik akan mendorong seluruh anggota masyarakat sekolah untuk meningkatkan kinerjanya agar tujuan sekolah dapat tercapai. Karena nilai, moral, sikap dan perilaku siswa selama di sekolah dipengaruhi oleh struktur dan budaya sekolah.

$$
\text { Budaya sekolah merupakan }
$$

karakteristik khas sekolah, kepribadian sekolah 
yang membedakan antara satu sekolahan dengan sekolahan lainnya. Menurut Masaon \& Tilomi (2011:179) bahwa "budaya sekolah diartikan sebagai sistem makna yang dianut bersama oleh warga sekolah yang membedakannya dengan sekolah lain". Guna menciptakan kultur sekolah yang bermoral perlu diciptakan lingkungan sosial sekolah yang mendorong murid-murid memiliki moralitas yang baik. Sebagai contoh, apabila suatu sekolah dapat menciptakan lingkungan sosial sekolah yang menjunjung tinggi kedisiplinan dan rasa tanggung jawab maka murid-murid dapat berkembang menjadi pribadi disiplin dan bertanggung jawab.

Sikap sekolah merupakan lingkungan belajar yang mendorong perilaku positif dan kepribadian siswa sehingga menciptakan proses pembelajaran yang optimal. Menurut Larsen dalam Moedjiarto (2002:28) bahwa "iklim sekolah merupakan suatu norma, harapan, dan kepercayaan dari personil-personil yang terlibat dalam organisasi sekolah yang dapat memberikan dorongan untuk bertindak guna pencapaian prestasi yang tinggi". Secara operasional, sebagaimana halnya pengertian iklim pada cuaca, sikap di sekolah dapat dilihat dari faktor-faktor seperti kurikulum, sarana, dan kepemimpinan kepala sekolah, dan lingkungan pembelajaran di kelas. Budaya dan sikap sekolah bukanlah suatu sistem yang lahir sebagai aturan yang logis dan tidak logis, pantas atau tidak pantas yang harus dan patut ditaati dalam lingkunga sekolah, tetapi budaya dan iklim sekolah harus lahir dari lingkugan suasana budaya yang mendukung seseorang melaksanakan dengan penuh tanggung jawab, rela, alami dan sadar bahwa apa yang dilakukan (ketaatan itu muncul dengan sendirinya tanpa harus menunggu perintah atau dibawah tekanan) merupakan spontanitas berdasarkan kata hati karena didukung oleh sikap lingkungan yang menciptakan kesadaran kita dalam lingkungan sekolah. Misalnya budaya disiplin, budaya berprestasi, budaya bersih dan asri.

Kebudayaan tidak dapat dipisahkan dari pendidikan bahkan kebudayaan merupakan alas dasar pendidikan. Pendidikan bukan hanya dialaskan kepada suatu aspek kebudayaan yaitu aspek intelektual tetapi kebudayaan secara keseluruhan, yaitu meyangkut nilai, norma dan tingkah laku. Sekolah diharapkan mampu menciptakan suasana yang kondusif untuk mewujudkan nilai-nilai karakter dalam tindakan sehari-hari disekolah. Kepala sekolah, guruguru, karyawan dan tenaga pendidik lainnya mampu menjadi contoh bagi siswa dan warga sekolah. Di lingkungan sekolah guru mempunyai kedudukan yang sangat penting dalam menciptakan situasi nilai-nilai karakter tersebut perilaku guru akan memberi warna terhadap watak peserta didik, diantaranya dengan cara: menciptakan kondisi sekolah yang mencerminkan nilai-nilai keberagaman, kemandirian, dan kesusilaan. Tata tertib dan kedisiplinan sangat penting artinya dalam mewujudkan budaya dan iklim sekolah yang kondusif melalui penciptaan kedisiplinan belajar. Dalam hal ini budaya dan sikap sekolah di SD Negeri Komplek BTN Pemda budaya dan sikap siswa yang ada masih banyak siswa yang datang terlambat, malas mengikuti pelajaranpelajaran membutuhkan hitungan seperti mata palajaran matematika, mengerjakan tugas-tugas di rumah (PR) belum tuntas dan masih kurang peduli terhadap kebersihan sekolah karna masih banyaknya mereka membuang sampah disebarang tempat, sehingga sangat mempengaruhi pola perilaku warga sekolah, terutama siswa yang sering menjadi soratan..Apabila budaya dan sikap sekolah itu terdapat baik maka karakter dan watak dari siswa tersebut juga baik.

Budaya dan sikap sekolah juga mempengaruhi sifat siswa, yaitu disiplin. Oleh karena itu sekolah harus memiliki tata tertib yang wajib di patuhi oleh seluruh warga sekolah. Tatatertib merupakan salah satu aspek yang mempengaruhi karakter disipin anak. Terjadinya perilaku tidak disiplin di sekolah tersebut menunjukkan bahwa telah terjadi permasalahan serius dalam hal pendidikan karakter disiplin. Munculnya perilaku tidak disiplin menunjukkan bahwa pengetahuan yang terkait dengan karakter yang didapatkan siswa 
di sekolah tidak membawa dampak positif terhadap perubahan perilaku siswa sehari-hari. Pada dasarnya siswa tahu bahwa perilakunya tidak benar tetapi mereka tidak memiliki kemampuan untuk membiasakan diri menghindari perilaku yang salah tersebut. Hal ini terjadi juga karena kurangnya perhatian guru dalam penanaman sikap dan perilaku disiplin pada siswa. Sikap dan budaya sekolah yang baik, kondusif dan tenang dapat mempengaruhi sikap disiplin pada siswa. Sikap dan budaya sekolah akan mempengaruhi proses dan hasil pendidikan khususnya pada anak, situasi lingkungan ini meliputi lingkungan fisik, lingkungan teknis dan lingkungan sosiokultural. Lingkungan fisis meliputi antara lain adalah lingkungan keluarga, sekolah dan masyarakat.

Berdasarkan uraian di atas maka perlu dilakukan sutau penelitian mengenai korelasi sikap disiplin terhadap budaya sekolah di SD Negeri Kompleks BTN Pemda Kota Makassar.

\section{METODE PENELITIAN}

Jenis penelitian yang digunakan dalam penelitian ini yaitu penelitian kuantitatif dimana pendekatan analisis menekankan analisisnya pada data-data numerikal (angka) yang diolah dengan metode statistika (Azwar, 2011: 5). Secara khusus penelitian ini merupakan jenis penelitian korelasional bertujuan mencari korelasi (pengaruh) variabel bebas (X) terhadap variabel terikat $(\mathrm{Y})$. dimana variable bebas yakni Sikap disiplin dan varibel terikat yakni budaya sekolah di SD Negeri Kompleks BTN Pemda di Kota Makassar.

Populasi dalam penelitian ini adalah siswa SD Negeri Kompleks BTN Pemda di Kota Makassar. Untuk populasi dalam penelitian ini adalah siswa kelas V SD Kompleks BTN Pemda dengan jumlah 276 siswa dengan karakteristik sebagai berikut:

1. Siswa SD Negeri Kompleks BTN Pemda kelas V Tahun Ajaran 2018-2019.

2. Masih terdaftar sebagai siswa kelas V di SD Kompleks BTN Pemda.

3. Masih aktif mengikuti semua mata pelajaran.

Pengambilan sampel dalam penelitian ini menggunakan teknik Simple Random
Sampling. sebanyak 74 siswa atau $25 \%$ dari populasi yang ada agar lebih representatif. Teknik pengumpulan data yang dipergunakan dalam penelitian ini akan menggunakan skala psikologi. Skala psikologi berupa konstrak atau konsep psikologis yang menggambarkan aspek kepribadian individu. Satu skala psikologi hanya diperuntukkan guna mengungkap suatu atribut tunggal (Azwar, 2011: 5-6). Skala ini akan mengukur baik variabel bebas yaitu sikap disiplin dan variabel terikat yaitu budaya sekolah.

Teknik analisis data yang digunakan dalam penelitian ini adalah analisis regresi. Dengan demikian, model persamaan regresi linear sebagai:

$$
\begin{gathered}
\mathrm{Y}=\mathrm{a}+\mathrm{bX} 1 \\
\text { Dimana: } \\
\mathrm{Y}=\text { Budaya Sekolah (Variabel Terikat) } \\
\mathrm{X}=\text { Sikap Disiplin (Variabel Bebas) }
\end{gathered}
$$

\section{HASIL DAN PEMBAHASAN}

Setelah dilakukan penelitian, selanjutnya dilakukan analisis data guna memperoleh gambaran keadaan atau kondisi sebenarnya sesuai dengan data yang diperoleh mengenai "Korelasi antar sikap disiplin terhadap budaya sekolah Di SD Negeri BTN Pemda Kota Makassar", maka pembahasan dapat dijelaskan sebagai berikut:

\section{Ada korelasi antar sikap disiplin terhadap} budaya sekolah di sekolah.

Budaya sekolah berarti tentang norma atau aturan dan kebiasaa/habit dimana suasana disekolah, proses belajar mengajar di kelas, komunikasi antar seluruh warga sekolah serta sarana dan prasarana di sekolah yang membentuk sikap disiplin siswa. Karena jika budaya yang ada di sekolah sudah baik maka siswa akan senang jika berada di lingkungan sekolah, bahkan dalam hal belajar pun siswa juga tidak bosan karna seluruh fasilitas yang ada memadahi. Sikap disiplin siswa terhadap pengaruh budaya sekolah dapat dilihat dari bagaimana pemahamannya tentang norma atau aturan dan kebiasaan yang mereka lakukan itu sendiri kemudian baru mengaplikasikannya dalam bentuk perbuatan yaitu diantaranya adalah sikap disiplin siswa. Sikap disiplin sekolah dikatakan baik jika seluruh warga 
sekolah mengerti apa arti pentingnya tentang budaya sekolah. Begitu pula budaya sekolah, budaya sekolah seperti yang selalu di terapkan yang telah menjadi kebiasaan sehari-hari tidak dapat dilepaskan misalnya budaya senyum, salam, sapa terhadap seluruh warga sekolah. Jika pelaksanaan budaya sekolah baik maka akan berpengaruh terhadap sikap disiplin siswa di sekolah.

\section{Penyajian Data Hasil Penelitian}

Peneliti melakukan observasi dan wawancara kepada siswa kelas V, guru kelas V, dan kepala sekolah untuk memperoleh informasi terkait dengan penerapan disiplin melalui budaya sekolah pada siswa kelas V SD Negeri BTN Pemda Kota Makassar.

1. Peraturan

a. Peraturan sekolah

Ada banyak peraturan di SD Negeri BTN Pemda Kota Makassar. Peraturan-peraturan sekolah tersebut dipasang di dinding sekolah dan juga dipasang pada setiap kelas agar siswa dan guru dapat membacanya. Kepala sekolah maupun guru ikut andil dalam pembuatan peraturan sekolah. Kepala sekolah dalam mensosialisasikan peraturan-peraturan tersebut dengan cara menyampaikannya kepada orang tua siswa saat rapat, ketika upacara, dan dimuat dalam web sekolah. Salah satu peraturan yang ada di SD Negeri BTN Pemda Kota Makassar yaitu siswa harus berada di sekolah 15 menit sebelum bel masuk berbunyi dan mengikuti kegiatan baris berbaris sebelum masuk kelas.

b. Peraturan kelas

Guru kelas V membuat beberapa peraturan untuk siswa kelas $\mathrm{V}$, namun peraturan kelas tidak dibuat secara tertulis, hanya berdasarkan kesepakatan secara lisan antara guru dan siswa. Ada peraturan kelas yang dilaksanakan dengan baik oleh siswa seperti mengerjakan piket dan izin ketika akan meninggalkan kelas saat pembelajaran, namun ada juga peraturan kelas yang kurang bisa dilaksanakan dengan baik oleh siswa kelas V, seperti mengumpulkan tugas atau PR, membuang sampah sembarangan, dan mengejek teman. c. Peraturan bermain

Saat siswa kelas V berada di luar kelas kepala sekolah tetap diruang kerjanya dan disamping itu, guru kelas $\mathrm{V}$ juga jarang mengawasi siswa ketika siswa sedang bermain, guru tidak setiap waktu ada di kelas, namun jika ada siswa yang bertengkar guru akan melerainya dan menasihati siswa yang bertengkar untuk saling meminta maaf.

Sikap disiplin siswa diketahui jarak interval dari 74 responden yang didapat adalah 7 interval dimana: Distribusi Frekuensi sikap disiplin siswa adalah: 13-19 sebesar 41,9\% dalam katagori Kurang Baik 20-26 sebesar $58,1 \%$ dalam katagori Baik.

Budaya Sekolah indikator normal dan aturan diketahui jarak interval dari 74 responden yang didapat adalah 2 interval dimana: Distribusi Frekuensi Indikator norma dan Dalam budaya Sekolah adalah: 5-6 sebesar $58,10 \%$ dalam katagori kurang Baik 7-8 sebesar 41,90\% dalam katagori Baik.

Budaya Sekolah indikator kebiasaan (habit) diketahui jarak interval dari 74 responden yang didapat adalah 2 interval dimana: Distribusi Frekuensi Indikator kebiasaan (habit) Dalam Budaya Sekolah adalah: 5-6 sebesar 47,3\% dalam katagori kurang Baik 7-8 sebesar 52,7\% dalam kategori Baik.

Pengujian Hipotesis secara sendirisendiri (X terhadap $Y$ ) $t_{\text {hitung }}=2,301$ dengan tingkat signifikansi atau alpa $=0,05$ dengan $2,301>0,05$. sedangkan persamaan regresinya dapat ditulis: $\mathrm{Y}=\mathrm{a}+\mathrm{bX}$ atau 16,296 +0,209X. Dari persamaan tersebut menunjukkan bahwa sikap disiplin berpengaruh signifikan terhadap budaya sekolah dengan nilai signifikan 2,301 > 0,05 , yang artinya bahwa $t_{\text {hitung }}>t_{\text {tabel}}$, maka dengan demikian Ho ditolak dan Ha diterima sehingga hipotesis yang diajukan dinyatakan diterima, atau dengan kata lain sikap disiplin siswa pengaruh signifikan terhadap budaya sekolah. dengan besarnya antara sikap disiplin terhadap budaya sekolah sebesar $10,5 \%$ dan pengaruhnya lemah berdasarkan interpretasi koefisien korelasi. 
Adapun pengaruh sikap disiplin terhadap budaya sekolah berdasarkan indikatorindikator dalam penelitian akan dideskripsikan penjelasannya sebagai berikut:

Indikator korelasi antar sikap disiplin seperti kepatuhan, kesetiaan dan ketertiban akan membawa pengaruh yang penting terhadap pembentukan tingkah laku, aspirasi dan interaksi sosial bagi anggota-anggota di dalamnya. Budaya sekolah sangat penting dalam membantu pelajar untuk belajar dengan tenteram dan tenang. Selain itu, apabila kawasan persekitaran sekolah yang cantik dan ceria, pelajar tidak akan jemu untuk hadir ke sekolah lagi karena merasa bahagia berada di kawasan sekolah. Hal ini bukan saja dapat mengelakkan masalah di sekolah dalam kalangan pelajar malah masalah disiplin pelajar dapat dikurangkan kerana emosi pelajar tidak terganggu. Hubungan antar personil seperti hubungan antar kepala sekolah dengan guru, kepala sekolah dengan siswa, guru dengan siswa, dan siswa dengan penjaga sekolah atau staf di sekolah dapat mempengaruhi budaya sekolah di dalam sekolah tersebut. Berdasarkan hasil pengolahan data, dapat dilihat dari 74 responden, menyatakan bahwa terdapat korelasi positif antar disiplin sekolah dan budaya sekolah dengan indikator hubungan antar personil dengan sikap disiplin siswa SD Negeri BTN Pemda Kota Makassar adalah 59 responden $(79,7 \%$.) menyatakan katagori kurang baik dalam hubungan antar personil dan 15 responden (20,3\%) menyatakan katagori baik dalam hubungan antar personil antara guru dan siswa. Siswa tidak setuju bahwa guru bersikap tertutup pada siswa. Sikap disiplin sekolah berpengaruh terhadap hubungan antar siswa dan guru dimana guru disini berperan sebagai bapak atau ibu yang bertugas sebagai pengayom dan pelindung mereka saat disekolah. Seharusnya guru dapat lebih memahami dan lebih dekat dengan siswa, jadi siswa akan merasa segan bukan karna takut melainkan karna siswa menghormati guru, dalam hal ini jika hubungan antara guru dan siswa berjalan dengan baik maka budaya saling menghargai di dalam sekolah tersebut juga akan berkembang dengan baik, tidak hanya di dalam sekolah pengaruh hubungan antar personil antar guru dan siswa akan mempengaruhi sikap disiplin siswa.

Indikator budaya sekolah yang merupakan norma atau aturan dan kebiasaan/habit didefinisikan sebagai seperangkat atribut yang memberi warna atau karakter, spirit, etos, suasana batin, setiap sekolah. Sebagaimana faktor seperti kurikulum, sarana dan prasarana, kepemimpinan kepala sekolah, dan lingkungan pembelajaran di kelas. Sarana dan prasarana yang ada di sekolah akan mempengaruhi iklim dalam sekolah tersebut. Jika sarana dan prasarana baik dan memadahi siswa akan merasa puas dan tercukupi segala keperluan untuk belajar di sekolah. Berdasarkan hasil pengolahan data, dapat dilihat dari 74 responden, yang menyatakan bahwa terdapat korelasi antar sikap disiplin dan budaya sekolah di SD Negeri BTN Pemda Kota Makassar adalah 50 responden $(67,57 \%$.) menyatakan katagori baik dalam sarana dan prasarana yang ada di sekolah dan 24 responden $(32,43 \%)$ menyatakan katagori kurang baik dalam sarana dan prasarana yang memadai yang ada di sekolah. Berdasarkan hasil perhitungan ini maka bahwa korelasi antar sikap siswa Terhadap budaya sekolah masuk ke katagori baik, dimana korelasi antar sikap disiplin dan budaya sekolah meliputi sarana dan prasarana sekolah yang ada. Sebagaimana yang dipaparkan diatas sarana dan prasarana di sekolah sangatlah penting dan berpengaruh terhadap sikap siswa. Maka dalam hal ini seharusnya baik dari pihak sekolah maupun dari siswa harus menjaga segala fasilitas dan sarana yang ada di sekolah. Karena segala hal yang ada di sekolah adalah kemilikan bersama bukan hanya tugas perseorangan saja yang harus menjaganya. Jika saran dan prasarana yang terjaga dengan baik, maka proses belajar mengajar pun akan nyaman untuk dilakukan. Siswa juga akan menerima haknya untuk menggunakan semua sarana dan prasarana yang ada, jadi siswa tidak merasa bosan berada di sekolah. Begitu pula jika saran dan prasarana yang terjaga dengan baik, maka siswa akan 
senantiasa untuk bersikap disiplin dengan rajin masuk kelas dan melaksanakan kegiatan di sekolah.

Indikator Norma dan Aturan Sekolah Budaya sekolah didefinisikan sebagai keseluruhan sistem berfikir, nilai, moral, norma, dan keyakinan itu adalah hasil dari interaksi manusia dengan sesama dan lingkungan alamnya (Doni Koesoema 2012: 125). Budaya sekolah yang baik akan mendorong seluruh anggota sekolah untuk disiplin dan tanggung jawab terhadap segala kewajibannya, karena nilai, moral, sikap dan perilaku siswa selama di sekolah dipengaruhi oleh struktur dan budaya sekolah. Salah satu pengaruh budaya sekolah adalah adanya tata tertib sekolah yang berisi tentang aturan dan norma. Dimana didalam tata tertib tersebut terdapat sanksi yang tegas bagi yang melanggarnya. Dalam hal ini perilaku warga sekolah pun dapat berjalan dengan baik jika tata tertib telah terlaksana sebagaimana mestinya.

Berdasarkan hasil pengolahan data, dapat dilihat dari 74 responden, yang menyatakan bahwa terdapat korelasi antar sikap disiplin siswa terhadap budaya sekolah dengan indikator norma dan aturan sekolah di SD Negeri BTN Pemda Kota Makassar adalah 43 responden $(58,10 \%$.) menyatakan katagori baik dalam norma dan aturan tingkat kedisiplinan yang ada di sekolah dan 31 responden $(41,90 \%)$ menyatakan katagori kurang baik dalam norma dan aturan yang yang ada di sekolah. Berdasarkan hasil perhitungan ini maka korelasi antar Sikap Disiplin dan budaya sekolah di SD Negeri BTN Pemda Kota Makassar masuk ke katagori baik, dimana siswa paham terhadap aturan dan norma yang ada di sekolah karna tegasnya sanksi yang berlaku. Maka dari itu, sanksi yang tegaslah yang diperlukan dalam mengatur sikap disiplin siswa. Dengan diberikan surat peringatan agar siswa tidak mengulangi kesalahan yang sama berulangulang dan agar siswa merasa jera. Kontribusi sikap disiplin terhadap budaya sekolah pada indikator norma dan aturan di sekolah berpengaruh terhadap sikap disiplin siswa karena jika norma dan aturan di sekolah diterapkan dengan sebaik-baiknya maka siswa akan disiplin untuk tepat waktu, dan takut jika melanggarnya karena adanya sanksi bagi pelanggarnya.

Indikator Kebiasaan (Habit) Budaya sekolah adalah suatu pola asumsi dasar pengembangan kelompok dalam mengatasi masalah-masalah dalam waktu lama yang menghasilkan keseluruhan sistem berfikir, nilai, moral, norma soaial yang dianggap valid dalam kehidupan sehari-hari. Budaya sekolah yang baik dapat mempengaruhi pembentukan karakter disiplin dan tanggung jawab pada siswa. Budaya sekolah yang baik dapat dilihat dari komponen input sekolahan, cotohnya seperti kebiasaan atau habit yang ada didalam sekolahan tersebut. Kebiasaan-kebiasaan yang sudah sering dilakukan di dalam bahkan di luar sekolah dapat mempengaruhi karaker siswa itu sendiri. Karena dengan kebiasaan yang dilakukan oleh siswa maka mereka akan cenderung melakukan hal-hal positif. Namun kebiasaan ini tidak hanya dilakukan oleh siswa, namun juga oleh seluruh warga sekolah karna seorang anak akan mengikuti apa yang di lihatnya sehari-hari. Berdasarkan hasil pengolahan data, dapat dilihat dari 74 responden, menyatakan bahwa terdapat pengaruh budaya sekolah terhadap habit atau kebiasaan siswa di SD Negeri BTN Pemda Kota Makassar adalah 35 responden $(47,3 \%$.) menyatakan katagori kurang baik dalam norma dan aturan tingkat kedisiplinan yang ada di sekolah dan 39 responden $(52,7 \%)$ menyatakan katagori baik dalam kebiasan (habit) yang yang ada di sekolah.

Berdasarkan hasil perhitungan ini maka bahwa korelasi antar sikap disiplin terhadap budaya sekolah sebanggian besar masuk ke katagori baik, dimana kebiasaan-kebiasaan yang ada di dalam sekolah masih tetap dilakukan walaupun tidak masuk dalam tata tertib yang mana kebiasaan akan mempengaruhi sikap siswa terutama sikap disiplin siswa di sekolahan. Pengaruh Budaya Sekolah meliputi kebiasaan (habit) di sekolah. Dapat diketahui bahwa kebiasaan akan mempengaruhi sikap siswa sehari-hari selama disekolah. Jika 
kebiasaan yang dilakukan selalu positif maka budaya sekolah yang ada akan terlihat tentram dan nyaman. Bentuk budaya sekolah yang asri dan nyaman terlihat dari segala perilaku dan tingkah laku warga sekolah, seperti senyum salam sapa. Penerapan senyum salam sapa yang dilakukan siswa kepada kapala sekolah, guru dan warga sekolah ini diharapakan dapat membentuk kebiasaan yang baik untuk generasi-terus menerus. Korelasi antar sikap disiplin (X1) dan budaya sekolah (Y) akan mempengaruhi seluruh hal yang ada di sekolah. Jika sikap disiplin yang ada berjalan dengan baik maka perilaku warga sekolah pun juga akan baik, salah satunya adalah budaya sekolah. Peran gurulah yang dapat membentuk suatu sikap disiplin siswa.

Berdasarkan hasil pengolahan data, dapat dilihat dari 74 responden yang menyatakan bahwa terjadi korelasi antar sikap disiplin terhadap budaya sekolah di SD Negeri BTN Pemda Kota Makassar. Hasil ini ditunjukan dengan pengujian hipotesis kedua dengan uji $\mathrm{F}$, Uji $\mathrm{F}$ menunjukan bahwa nilai Fhitung sebesar 4,772 dengan tingkat (sig.) 0,011 atau dapat nilai signifikasi 0,011 lebih besar dari nilai probabilitas 0,005 , dimana koefisien determinasi (R2 ) sebesar 0,94 hal ini menunjukan bahwa sikap disiplin siswa berpengaruh $94 \%$ terhadap budaya sekolah dan sisanya $6 \%$ dipengaruhi oleh variable lain yag tidak teliti. Berdasarkan hasil uji $F$ nampak bahwa ada korelasi positif dan signifikan antar sikap disiplin variable berpengaruh terhadap budaya sekolah di SD Negeri BTN Pemda Kota Makassar. Dengan demikian $\mathrm{H}^{0}$ ditolak dan $\mathrm{Ha}$ diterima berarti terdapat pengaruh yang positif antara sikap disiplin terhadap budaya sekolah di SD Negeri BTN Pemda Kota Makassar.

\section{KESIMPULAN DAN SARAN \\ Kesimpulan}

kesimpulan dari penelitian ini bahwa terdapat korelasi positif dan signifikan antara sikap disiplin terhadap budaya sekolah, ini berarti semakin baik sikap disiplin akan sangat mendukung budaya sekolah, dalam penegakan norma atau aturan serta kebiasaan/habit.
Sebaliknya semakin buruk sikap disiplin siswa dalam hal kepatuhan, kesetian dan ketertiban, maka budaya sekolah norma atau aturan serta kebiasaan/habit semakin rendah. Sikap dan budaya sekolah yang baik, kondusif dan tenang dapat mempengaruhi sikap disiplin pada siswa. Sikap dan budaya sekolah akan mempengaruhi proses dan hasil pendidikan khususnya pada anak, situasi lingkungan ini meliputi lingkungan fisis, lingkungan teknis dan lingkungan sosiokultural.

\section{Saran}

Terdapat beberapa hal yang perlu disarankan dari hasil penelitian ini, pertama untuk siswa. Bahwa siswa harus kenal budaya sekolah yang ada di sekolah dengan baik, serta dapat meningkatkan budaya sekolah dengan cara terus meningkatkan kedisiplinannya di sekolah baik di dalam kelas maupun diluar kelas. Kedua saran untuk Guru, yaitu menjadi menjadi teladan dan motivator bagi siswa agar dapat memahami dan membiasakan diri memiliki sikap kasih sayang terhadap siswa dengan cara kepedulian kepada siswa agar siswa dapat mengenal dan mencintai dirinya sendiri serta dapat menghargai sekelilingnya.

\section{DAFTAR RUJUKAN}

Adisusilo, Sutarjo. (2013). Pembelajaran nilai karakter, kontruktivisme \& VCT sebagai inovasi pendekatan pembelajaran afektif. Jakarta: PT Raja Gravindo Persada.

Arikunto, Suharsimi. (2006). Prosedur Penelitian Suatu Pendekatan Praktik (Eds VI). Jakarta: Rineka Cipta.

(2010). Prosedur

Penelitian Suatu pendekatan Pratik. Jakarta: PT Rineka Cipta.

Agus, Sasmito. (2012). Pengaruh Disiplin Belajar dan Lingkungan terhadap Hasil Belajar Mata Pelajaran Ekonomi Kompetensi Dasar Menafsirkan Persamaan Akuntasi pada Siswa Kelas XI IPS SMA Mardisiswa Semarang Tahun Pelajaran 2011/2012. Jurnal. Vol 1 No. 1. Halaman 1-7. UNNES. 
Azwar, Saifuddin. (2011). Metode Penelitian. Yogyakarta: Pustaka Pelajar

Daryanto. (2015). Pengelolaan budaya dan iklim sekolah. Yogyakarta: Gava

Direktorat Jendral Peningkatan Mutu Pendidik dan Tenaga Kependidikan Departemen Pendidikan Nasional.(2007). Pengembangan Budaya dan Iklim Pembelajaran di Sekolah. Jakarta.

Jia, Yueming. (2009). The Influence of Student Perceptions of School Climate on Socioemotional and Academic Adjustment: A Comparison of Chinese and American Adolescents. Jurnal. Volume 80, No. 5, Pages 1514-1530

Listyani, Puri. (2005). Pengaruh Disiplin Belajar Dan Iklim Sekolah Terhadap Prestasi Belajar Siswa Kelas II SMK Negeri 5 Semarang, Skripsi. Semarang: UNNES.

Lacopa, Arga dan Ismani. (2012). Pengaruh Kedisiplinan Siswa Dan Persepsi Siswa Tentang Kualitas Mengajar Guru Terhadap Prestasi Belajar Akuntansi Siswa Kelas XI IPS MAN Yogyakarta II Tahun Ajaran 2011/2012. Jurnal. Vol. X No. 2. Halaman 22-42. UNY

Kikyuno. (2012). Makalah budaya sekolah. Blogspot.com. Mei 2012

Margono, S. (2005). Metodologi Penelitian Pendidikan. Jakarta: Rineka Cipta

Marzuki, Ide Lia: (2015). Pengembanagn budaya dan iklim sekolah di SMA Negeri 2 Bandar Lampung. Lampung.

Mediauchid, Damiyanti. (2015). Model pendidikan karakter. Yogyakarta: Yogyakarta

Mustari, Mohamad (2014). Nilai Karakter Refleksi Untuk Pendidikan. Jakarta:PT Raja Gravindo Persada.

Nurgiantoro, B dkk. (2002). Statistik Terapan Untuk Penelitian Ilmu-Ilmu Sosial.Yogyakarta: Gadjah Mada Universty Press.

Prijodarminto, Soegeng. (2009). Disiplin Kiat Menuju Sukses. Cetakan Keempat. Jakarta: PT Abadi.

Peraturan Menteri Pendidikan dan Kebudayaan
Republik Indonesia No. 24 Tahun 2016. (2016) Tentang Kompetensi Inti dan Kompetensi Dasar Pelajaran. Jakarta. Inanna, I. (2018). Peran Pendidikan Dalam Membangun Karakter Bangsa Yang Bermoral. JEKPEND" Jurnal Ekonomi Dan Pendidikan", 1(1), 27-33.

Rahmatullah, R. (2018). Pembelajaran Ekonomi Berjatidiri Bangsa. JEKPEND: Jurnal Ekonomi Dan Pendidikan, 1(1), 10-16. https://doi.org/10.26858/jekpend.v1i1.505 5

Rahmatullah, R., \& Inanna, I. (2017). Identifikasi Nilai-Nilai Ekonomi Sebagai Dasar Merumuskan Materi Pengantar Ilmu Ekonomi Berjatidiri Bangsa. Prosiding Seminar Nasional, 700-704. Retrieved from http://eprints.unm.ac.id/11439/1/PROSIDI NG NASIONAL MEMBANGUN INDONESIA.pdf

Rahmatullah, R., Inanna, I., \& Nurdiana, N. (2019). Ethnopedagogi dalam pembelajaran ekonomi. Seminar Nasional Lembaga Penelitian UNM, 284-288.

Redan, Basilius. (2012). Hubungan Ketrampilan Managerial Kepala Sekolah, Iklim Sekolah, dan Moral Kerja Guru dengan Kinerja Guru SMA Negeri di Kota Merauke. Jurnal. Vol. 10. No. 3. Universitas Musamus Merauke

Rustiyan: (2011). Pengaruh kepemimpinan kepala sekolah, iklim kerja sekolah danmotivasi kerja guru terhadap kompetensi pedagogik guru Sekolah Menengah Atas Negeri di Kabupaten Pringsewu. Lampung.

Rohman. (2012). Pengaruh Pembelajaran pendidikan kewarganegaraan (PKn), Budaya sekolah, dan Kecerdasan Emosional terhadap aplikasi nilai-nilai karakter bangsa pada siswa adiguna bandar lampung. UNILA. Lampung.Tesis tidak diterbitkan.

Sutisno, Rawita. (2013). Mengelola Sekolah Efektif (Perspektif Managerial dan Iklim Sekolah. Yogyakarta: Laks Bang Preesindo.

Sudjana. (2012). Metode Statistika. Tarsido: Bandung 
Kadariah, M. Jafar B, Hasmiah, Sukarman, Korelasi Antar Sikap Disiplin... | 63

Sugiyono.(2012). Metode Penelitian

Kuantitatif, Kualitatif $R$ dan $D$.

Alfabeta.Bandung.

Suprapto. (2013). Meodologi Penelitian Ilmu

Pendidikan dan Ilmu-ilmu pengetahuan

sosial. Yogyakarta: CAPS. 